\title{
What Influences the Repurchase Intention for Luxury Brands?-The Relative Impacts of Luxury Value Dimensions
}

\author{
Alev Kocak Alan ${ }^{1}$, Inci Dursun ${ }^{2}$, Ebru Tumer Kabadayi ${ }^{1}$, Kenan Aydin ${ }^{3}$, Fikret Anlagan ${ }^{1}$ \\ ${ }^{1}$ Department of Business Administration, Gebze Technical University, Kocaeli, Turkey \\ ${ }^{2}$ Department of Business Administration, Yalova University, Yalova, Turkey \\ ${ }^{3}$ Department of Business Administration, Yildiz Technical University, Istanbul, Turkey \\ Correspondence: Alev Kocak Alan, Department of Business Administration, Gebze Technical University, PK: 141, \\ Kocaeli, Turkey. Tel: 00902626051426. E-mail: akocak@gtu.edu.tr
}

Received: February 10, 2016

doi:10.5539/ibr.v9n5p11
Accepted: March 2, $2016 \quad$ Online Published: March 16, 2016

URL: http://dx.doi.org/10.5539/ibr.v9n5p11

\begin{abstract}
This paper investigates the main antecedents of repurchase intention for luxury brands. In addition to the traditional understanding of repurchase by trust and satisfaction this study specifically focuses on the relative and indirect impacts of luxury value drivers. Four different facets of luxury value (i.e. social value, individual value, financial value and functional value) were proposed to influence repurchase intention through encouraging brand trust and brand satisfaction. The researchers administer a survey to 500 undergraduate students in consideration of the luxury product -sunglasses- which they bought recently. Data analysis was performed using structural equation modeling. Results confirmed some of indirect encouraging effects of luxury value dimensions on repurchase intention. Functional and financial facets of luxury value were found to be essential for consumer satisfaction while individual value provided by a luxury brand was the main driver for consumer trust. Results, managerial implications and future research directions are discussed.
\end{abstract}

Keywords: luxury value, brand satisfaction, brand trust, repurchase intention

\section{Introduction}

Luxury market is a central research area in the literature of marketing in general (Vigneron \& Johnson, 1999, 2004) and retailing in particular (Jung et al., 2012; Li et al., 2012). Beyond the dynamics of growth in the global luxury brands, it is a critical subject for marketers to understand the underlying mechanism of customer's perception of luxury value and motivation for buying luxury brands and how to utilize the information gleaned from customer provide managers to gain competitive advantage and develop marketing programs, effective campaigns etc. regarding their luxury products range (Huber et al., 2001). Based on those important aspects, major objectives of researches are to investigate how to predict key determinants of customers' purchase intention (Chattalas, 2015), patronage intentions (Keng et al., 2007), commitment (Kim et al., 2006), loyalty (Li et al., 2012) and attitude (Lee \& Hwang, 2011) towards luxury brands.

The paradoxical notion of luxury arises the need to understand the luxury customers' behavior and intention because of that fact, considerable attention is devoted by retailing researchers during the past years (Chandon et al., 2016). Previous studies, in retailing context, generally analyzed the purchase decision of luxury brands (eg., Srinivasan et al., 2014; Hung et al., 2011); luxury consumption behavior (eg., Veblen, 1899; Suto, 1979; Kastanakis \& Balabanis, 2014); comparisons of motivations across cultures and demographic features (e.g., Wang \& Waller, 2006; Stokburger-Sauer \& Teichmann, 2013); comparison between genuine and counterfeit goods (eg., Hennigs et al., 2012); concept of ethical-luxury (e.g., Davies et al. 2011); luxury branding strategies (eg., Okonkwo, 2009); customer segments based on attitudes (Dubois \& Laurant, 2005) and the process of customer value toward luxury (e.g., Shukla \& Purani, 2012). Considerable amount of these studies paid attention to understand why today's customers buy luxury goods and how their perception of luxury value shapes their purchasing intention (Wiedmann et al., 2007).

In the studies, it is mentioned that marketers need to use different approach for marketing luxury goods than the other types of goods (Dubois \& Duquesne, 1993) and analyzed their customer value system to understand which benefits of luxury goods compensate overcharge (Tynan et al., 2010). Therefore many studies focused on customers' luxury value perception (Hennigs et al., 2012; Wiedmann et al., 2007, 2009). Wiedmann et al. (2007) offered a conceptual model for customers' luxury value perception and they indicated that the luxury value perception of and motivation for luxury 
brand purchasing is engaged to the nature of the financial, social, individual and functional benefits of a brand.

However, there is now little consensus about the dimensions of luxury value. Drawing by generally accepted importance of luxury value as a concept to both academic researchers and business practitioners, this paper further develops the luxury value concept for researchers and marketers of luxury goods and intends to fill this research gap by proposing a holistic framework of customer satisfaction, brand trust and luxury purchase intentions. The simultaneous examinations by using structural equation analyses allow us to characterize the magnitude of the each constituent of luxury value perceptions (i.e. social, individual, financial and functional) in the existence of other constructs. As a consequence current study contributes to a more holistic view to the complex phenomenon of luxury consumption by identifying luxury customers according to the dimensions that lead their value perception and consumption style. Associating related theoretical and empirical findings, this study sets new insights on understanding why customer is buying "luxury" from customers' perspective.

The structure of current paper is as follows. First, we review the prior researches on luxury consumption literature and establish a conceptual framework. This framework is organized around the four fundamental dimensions that underlie value perceptions; i.e. social, individual, financial and functional and their relationship between brand trust, customer satisfaction and purchase intention. Next, the methodology is explained in detail, and estimation methods are evaluated. On the last section empirical findings are discussed and we draw theoretical as well as managerial implications along with limitations and directions for future researches.

\section{Background}

It is a well-known fact that luxury is a main factor that differentiates a brand in a product range, (Kapferer, 1997) and one of the leading drivers of customer preference and usage (Dubois \& Duquesne, 1993). Grossman and Shapiro (1986, p.82) entitle luxury goods as status goods and define as" goods for which the mere use or display of a particular branded product confers prestige on their owners, apart from any utility deriving from their function". Luxury goods have some superior characteristic of high quality, aesthetics, premium price, exclusiveness and providing self-respect and appreciation by society (Heine \& Phan 2011; Mattila, 1999). Anciently the context of luxury was only involved with the products like wines, cars, garments and watches and it was only available for elites but nowadays with the increasing level of income it is demanded by large masses and applicable in a wide range of products and services (Srinivasan et al., 2014). However, although the volume of the luxury market has been incrementally growing over the past years and the literature of marketing has recently paid considerable amount of interest in the study of luxury consumption, there is little known about why customers buy luxury brands (Vigneron \& Johnson, 2004).

The literatures of marketing especially emphasize the underlying reasons of buying luxury brands to get admired by public (Srinivasan et al., 2014), show their status to in the public (Han et al., 2013), have experience of pleasure, beauty and aesthetics (Walls et al., 2011), experience excellent un-findable quality in ordinary products (Hansen \& Wänke, 2011). In fact purchasing tendency of a luxury brand not only intention to have someone under his/her spells or purposes to show status, but also does something more than them (Dion \& Arnould, 2011). Luxury consumption helps person to satisfy their personal needs and it is associated with their value perception (Srinivasan et al., 2014). As it is mentioned in the past researches the value perception of the luxury consumption can not only deal with either hedonic oriented view or status oriented view (Hennings et al., 2012). According to Atwal and Williams (2009) "the marketing of luxury goods has become increasingly complex, being associated not only with conveying an image of quality, performance and authenticity, but also with attempting to sell an experience by relating it to the lifestyle constructs of customers". Hence from that perspective and based of the studies of Wiedmann and his friends (2007, 2009), luxury goods can satisfy customers' functional, social, individual and financial needs and these four constructs are main drivers of customers' value perception. Indeed, it is a common knowledge that value that derived from a product or service consumption is one of the main determinant of purchase intention of individual (Chattalas \& Shukla, 2015). In this context, the concept of value is defined as an overall subjective evaluation of product or service usage considering all related assessment criterion of individual (Zeithaml, 1988) and as stated before, research demonstrates that four fundamental dimensions namely functional, social, individual and financial value perceptions, as well as the specific constituents of each, are most important determinant of luxury value perceptions (Wiedmann et al., 2007; Hennigs et al., 2012). Consistently, in the current research, luxury value is conceptualized as a four-dimensional concept. Given luxury value dimensions consist of (1)_functional value dimension (including usability value and quality value sub-dimensions), (2) social value dimension (covering conspicuousness value and prestige value sub-dimensions), (3) individual value dimension (through self-identity value, hedonic extravagance value, hedonic life enrichment value, hedonic self-gift giving value and materialistic value) and (4) price value dimensions.

\subsection{Luxury Value Drivers /Functional Value}

The functional value of luxury in a product or service related functions refer to the subjective perception of quality and 
usability when consuming the product or service (Hennigs et al., 2012). The product or service offerings are perceived as key drivers for satisfying the individual' need to perform functional value (Berthon et al., 2009). Broadly, the main reason for designing a product or service is providing core benefit to customer by fulfilling his/her needs. Owing luxury goods or services is associated with a superior brand equity and quality in customers' mind (Aaker, 2009). Therefore luxury enriched product or service is enhanced a customer's desire or preference for buying it (Hennigs et al., 2012). On that note, luxury products help the customers to express their usability value and quality value perception (Wiedmann et al., 2009).

\subsection{Luxury Value Drivers/Social Value}

Beyond theirs' functional benefits, luxury brands are usually better in providing subjective intangible social benefits to customers (Vigneron \& Johnson, 1999). The notion of social value is based on the researches about the construct of individuals' cooperation and competition with their social environment (Chattalas, 2015). Customers use luxury brands because it is considered by many people to be the reflective of social status, as a symbol of the social prestige and self-identity (Hung et al., 2011). Studies states that social value perception motivates customers to possess products according to their self-identity and their social reference group members' preferences (Shukla, 2012). Vigneron and Johnson (2004) proposed that different; luxury brands can provide to their customers' different types of value like prestige value and conspicuousness which can classify as main drivers of social value (Wiedmann et al., 2009). Prestige value makes individual feel that luxury brand is only for the selected few ones and consuming luxury is considered as a symbol of success (Hung et al., 2011). Conspicuousness value has an importing motivating force that influence individual for buying luxury brand because of the prestige perception, improving self-image and the symbol of status (Truong \& McColl, 2011).

\subsection{Luxury Value Drivers/ Individual Value}

From a larger perspective in investigating customer motivation for buying luxury product or services, socially oriented motivation is not enough for deep understanding the whole reason for purchasing luxury (Strizhakova et al., 2008). The individual value dimensions concentrate on an individual's self motivation on the consumption of luxury (Shukla et al., 2009). The main constituents of individual value are mentioned as self identity, hedonic-self gift giving, hedonic-extravagance, hedonic-life enrichment and materialistic value (Wiedman et al., 2009). Referring to individuals' self identity is a consistence of the features of luxury product and ones characteristics (Vigneron \& Johnson, 1999). Hedonic-self gift giving value means that purchasing luxury products can be seen as giving gift to individual for celebrating an occasion that she/he believes significant for her/his self and buying luxury products is a way for treating her/his self (Wiedman et al.,2009). The other sub-dimension of individual value, hedonic-extravagance value is defined as arouse pleasure in one's mind while buying things and the main shopping motivation of one, who is more intended hedonic-extravagance value, is spending money even for non-functional things (Wiedman et al.,2009). The other main driver of individual value is called hedonic-life enrichment value that occurs during luxury consumption and gives the perception of one' mind self-actualization and provides deeper meaning in his/her life (Wiedman et al., 2009). The last dimension of individual value, materialistic value can be defined as the level of one' essentially thought about possession and acquisition to play an important part in his/her life (Wiedman et al., 2009). Highly materialistic individuals may admire people who own expensive homes, cars and clothes and like to own things that impress people (Wiedman et al., 2007). This shows that individual value is an inherent phenomenon and personal orientation of the customer towards luxury products.

\subsection{Luxury Value Drivers/Financial Value}

The fourth dimension is the financial value of the product. This is about pecuniary facet of luxury consumption. It is well known fact that luxury products are related with premium price (Srinivasan et al., 2015). High price is thought as an indicator of high quality and status (Vigneron \& Johnson, 1999). In this context it is supposed that high quality satisfies customer needs and buying luxury products, owing prestige brands is a symbol of status and wealth (Wiedman et al., 2007).

\section{Role of Luxury Value in Repurchase Decision Process}

This research examines the role of luxury value from a multidimensional view and investigates the role of luxury value on brand satisfaction, brand trust and repurchase intention in luxury product settings. As such, compared with previous studies in this research area, this study provides a more elaborate screening of the mechanisms through which luxury consumption separately influence level of individual' brand satisfaction, brand trust and consequently repurchase intention. Although there have been a lot of researches on customer value and relationship between customer outcomes, to the best of our knowledge, few of them studied the relational outcomes of luxury customer value, especially in product concept, in emerging markets like Turkey. In addition, the framework proposed and examined in the present study provides several novel prescriptions for practicing luxury product providers: the effect of luxury value can be 
examined in terms of the distinct and multiple dimensions. Figure 1 presents the research model.

Figure 1. Research Model

\subsection{The Impact of Luxury Value on Brand Satisfaction}

Satisfaction has been comprehensively discussed as a cognitive evaluation (Hasan et al., 2009). The most widely implemented and accepted model for satisfaction belongs to Oliver (1980) - Expectancy \& Disconfirmation model. In this model Oliver (1997, p. 13) defines satisfaction as "a judgment that a product or service feature, or the product or service itself, provided (or is providing) a pleasurable level of consumption- related fulfillment, including levels of under or over fulfillment". With regard to expectancy and disconfirmation model, satisfaction arises after the evaluation of customers' brand experience (Wu \& Liang, 2009). Creating and keeping lasting relation with customers may comprise a value creating activities of brand experiences (Smith \& Colgate, 2007). Previous studies make contribution to identify and conceptualize of luxury value (Vigneron \& Johnson, 2004; Wiedmann et al., 2007; Wiedmann et al., 2009). Strategic importance of creating luxury value through close relationships via memorable and unique brand experiences induces brand satisfaction, trust, cognitive and affective commitment and as well as repurchase intention (Li et al., 2012; Smith \& Colgate, 2007; Wiedmann et al., 2012). For this reason; creating a strong, long term relationship with a brand through customer value is one of the main success factors for luxury brands. As discussed before; social values, authenticity based values like functional values, personal and hedonic based values that are connected with emotional status, experiences such as individual and price values are the core competence of luxury value (Kapferer \& Bastien, 2009).

Customers' favorable perceptions of luxury value should be associated with positive customer outcomes like greater satisfaction with the product ( $\mathrm{Li}$ et al., 2012). The customers who are a part of the upper class would achieve satisfaction from the others' reaction to the wealth that they gained by consuming luxury products arrestingly (Teimourpour \& Hanzaee, 2011). Studies mention that customers' status-seeking behavior, which is the main driver of social value, is related with their luxury brand satisfaction (Eastman et al. 1999). Likewise Chattalas (2015) findings show that functional value perceptions drive behavioral intentions of customers. O'Cass and McEwen (2004) suggest that one of the main motivations for luxury consumption is internal reasons like self reward or external reasons like signal of wealth which are mentioned as the underlying mechanism of individual value and financial value. Shukla and Purani (2012) assert that individual value motive customers consider emotional based brand experience and satisfaction. Finally, however all of these value dimensions operate self-directly, they interrelated with each other and have many effects on luxury value perceptions and behaviors. Therefore we suggest for each value dimension that;

$H 1 a$ - Functional value is positively related to brand satisfaction

$H 1 b$ - Social value is positively related to brand satisfaction 
HIc- Individual value is positively related to brand satisfaction

$H 1 d$ - Price value is positively related to brand satisfaction

\subsection{The Impact of Luxury Value on Brand Trust}

Together with satisfaction and repurchase intention, the other key component for the luxury value to be able to pursue long-term relationships is the brand trust (Chaudhuri \& Holbrook, 2001; Ling et al., 2010). It is an important and basic element for the luxury product customers to experience trust with the brand that will fulfill the promises and establish honesty and benevolence (Moliner et al., 2007). Trust indicates that brand commitment extinguish suspense and generate open and honest communication for both parties (Czepiel, 1990). Although there have been lots of definitions of trust is existing in the marketing literature, the most popular one was done by Morgan and Hunt (1994, p. 23), which they assume that trust exist "when one party has confidence in an exchange partner's reliability and integrity". Likewise, Moorman et al. (1993, p. 82) conceptualize trust as "a willingness to rely on an exchange partner in whom one has confidence". While the two conceptualizations are very kindred, we conceptualize brand trust as the willingness of the upper class' consumers to count on the ability of the luxury brand to perform its emphasized functions.

Luxury value is an overall consideration of the benefits and all costs of luxury brands (Shukla \& Purani, 2012) and in the current marketing literature, it is a well-known fact that these luxury value dimensions play a part in evaluation process for luxury products purchase decision (Wiedmann et al., 2007; 2009). Luxury value is conceived to include functional, social, individual and price value. The expediency obtained from the usability and the quality of the luxury brand is called functional value. The expediency obtained from the owned luxury brand that enhances social self-concept, conspicuousness and prestige is social value. The expediency obtained from the brand due to its premium price is financial value. The expediency obtained from self identity, hedonic extravagance, hedonic life enrichment, hedonic self gift giving and materialistic is individual value. Both expediencies and costs are dealt as a miscellaneous constructs. In respect of the relationship between the luxury value and brand trust, Morgan and Hunt (1994) conceive that the expediencies are predictors of brand trust. The luxury value of a brand can be considered multifaceted construct of the expediencies of the relationship. Therefore, it can be supposed that the luxury value of a brand act as an antecedent of brand trust in the luxury context (Punniyamoorthy \& Raj, 2007; Sirdeshmukh \& Singh, 2002; Song et al., 2012). In similar vein, we propose that:

$H 2 a$ - Functional value is positively related to brand trust

$H 2 b$ - Social value is positively related to brand trust

$H 2 c$ - Individual value is positively related to brand trust

$H 2 d$ - Price value is positively related to brand trust

\subsection{The Impact of Brand Satisfaction on Brand Trust}

In a commercial view, brand satisfaction can be identified as a cognitive assessment of whether or not the interchange relationship within the compass of the brand is conferment (Oliver, 1980). Inversely, in communal view, this relationship contains feelings about others and brand trust is an important issue of this relationship (Esch et al., 2006). When individual is satisfied with the performance of the brand, he/she develops positive feeling to that brand, and this brand affect conducts to greater commitment to specified brand (Chaudhuri \& Holbrook, 2001). Concurrently, individual consolidates his/her belief that the brand will pursue to meet his/ her expectations, its responsibilities and specified performance (Song et al., 2012). In marketing literature this close relationship between brand trust and brand satisfaction has been discussed (Delgado-Ballester \& Luis, 2001; Garbarino \& Johnson, 1999; Zboja \& Voorhees, 2006). Most of the findings suggest that brand satisfaction behave as an antecedent of brand trust in the relationship between satisfaction and trust (Delgado-Ballester \& Luis, 2001; Ha \& Perks, 2005). More specifically, these studies mention that when the individual experiences a high level of brand satisfaction, he/she decides to keep long term relationship within the existing brand and override his/her unfavorable behavioral intentions. Therefore, the following hypothesis is proposed:

H3- Brand satisfaction is positively associated with brand trust

\subsection{The Impact of Brand Satisfaction and Brand Trust on Repurchase Intention}

Customer satisfaction draws interest in the marketing literature because of its potential effect on customer behavioral tendency and retention (Cronin et al., 2000). Wirtz and Bateson (1999) emphasized that customer satisfaction is a cognitive outcome of an evaluation between expectations and perceived performance of customer. Gibson (2005) mentioned that the level of customer satisfaction shaped their post-purchase decision. If individual became a satisfied customer, he/she would buy the product again and give his/her friends and families positive feedback (Wu \& Liang, 2009). Likewise; the literature shows some supportive of the link between customer satisfaction and past purchase 
intention (e.g., Caro \& García, 2007; Walsh et al., 2010). Therefore, it is reasonable to expect that;

$H 4$-Brand satisfaction is positively associated with repurchase intention

The emphasis of brand trust in designing covetable customer outcomes is well reported in the literature of marketing (Esch et al., 2006; Kabadayi \& Alan, 2012). To concern its outcomes; Morgan and Hunt (1994) and Delgado-Ballester and Luis (2001) consider the construct of trust as a center of long term relationship within a brand. Because, trust is an important element that indicates believable promises for both parties and commitment, one of the main driver of long term relationship, is formed by the keeping promises by the brand. The literature shows that brand trust plays as an antecedent of commitment (Xingyuan et al., 2010). Ranaweera and Prabhu (2003) suggest both trust and satisfaction to have favorable effects on customer outcomes. Finally, both Delgado-Ballester et al. (2003) and Zboja and Voorhees (2006) find that satisfaction has an impact on customer retention both directly and indirectly through trust. Taking into the account the condition of brand trust motivate the individual to repurchase the brand. Consequently, we proposed that;

H5-Brand trust is positively associated with repurchase intention

\section{Methodology}

\subsection{Sample}

The data used to test the hypotheses was collected through a survey conducted in Istanbul, Turkey. Istanbul is the most crowded city of the country with the population of 14.377 .018 which is $18.5 \%$ of the total population of Turkey (TUIK, 2016). The city is hosting the most of luxury stores, hotels and restaurants and considered as center of the luxury market in Turkey. The sample consists of students attending various undergraduate programs of five public and eight foundation universities in Istanbul. After selection of the universities participants were chosen through convenience sampling method. A total of 500 valid responses were obtained after the elimination of unusable questionnaire. Descriptive statistics for the sample is shown in Table 1.

Table 1. Descriptive Statistics (n: 500)

\begin{tabular}{llll}
\hline Age & Valid Percent & Income (Turkish Lira) & Valid Percent \\
\hline $17-20$ & 48.80 & Less than 1.000 & 2.69 \\
$20-25$ & 49.90 & $1.001-2.000$ & 13.04 \\
Older than 25 & 1.40 & $2.001-3.000$ & 17.81 \\
Gender & Valid Percent & $3.001-5.000$ & 25.05 \\
Female & 54.55 & $5.001-7.000$ & 14.70 \\
Male & 45.45 & More than 7.000 & 26.71 \\
\hline
\end{tabular}

\subsection{Measurements}

All constructs were measured using multiple item five point Likert type scales (Strongly Disagree $=1$ and Strongly Agree $=5$ ). Each facet of luxury value sub-dimensions was measured using selected items from validated scales from the literature. A four-item price value scale was adopted from Mathwick et al. (2001). Four items focusing on prestige value were selected from Hung et al. (2011). The three items were adapted from Truong and McColl (2011) to measure conspicuousness value. Usability value items were drawn from Wiedmann et al. (2009). Six items of quality value scale of Truong and McColl (2011) were used. Six-item materialistic value scale of Sharma (2009) was employed. To asses self -identity value three items were drawn from Wiedmann et al. (2009). Hedonic value sub-dimensions (life enrichment, self-directed pleasure, extravagance) of individual value were measured using a total of eight items adopted from Wiedmann et al. (2009). As a dependent variable satisfaction was assessed using a six-item scale combined of the selected items from the scales of Westbrook and Oliver (1981), Cole et al (1993), Fitzsimons et al. (1997). For the measurement of trust tree items were adopted from the respective scales of Lau and Lee (1999) and Chaudhuri and Holbrook (2001). Finally, a four item scale was used to assess the repurchase intention. 3 items were selected from Zeithaml et al. (1996), Westbrook and Oliver (1981) and Fitzsimons et al., (1997). The last item of the scale was added by researchers based on the experiences on previous researches. The questionnaire also included items regarding demographics factors.

\subsection{Pilot Studies}

The data was collected with respect to a luxury brand. A two step pilot study was conducted on undergraduate students to determine the product and luxury brands in that products category to use in the research. At the first stage of the pilot study sun glasses appeared as more commonly known and purchased products with many alternative brands, different levels of quality, price and prestige. Moreover different luxury dimensions can be assessed through sunglasses since they provide both functional and hedonic-symbolic benefits. Finally, sunglasses are used by both males and females facilitating the sampling procedure. In conclusion, sunglasses were found to be one of the most appropriate products for the research. 
In this study luxury were operationalized based on the perception of luxury. For this reason, at the second stage of the pilot study 42 students were asked to indicate three of luxury sunglasses brand they remember. Most often indicated seven brands were considered as luxury brands.

These brands were listed on the top of the main questionnaire. Respondents were asked to check the sunglasses brand they had bought most recently and answer the questions thinking about that brand. There were also an "other brands" option for respondents who did not buy any of the luxury brands listed. The questionnaires with "other brand" response were not taken into consideration.

Before main survey the questionnaire was pretested on 100 undergraduate students from various universities in Istanbul and Kocaeli, Turkey. Some items were revised for clarification of meaning.

\subsection{Measurement Analyses}

Measurement quality was evaluated through a multi- stage process including a series of confirmatory factor analysis. The data was split into two sets to enable to test the modified measurement model on unseen data. Accordingly, the first data set was used for initial testing and modifying the measurement model and the second set was used for the test of respecified measurement model and hypothesis testing.

\subsubsection{First Stage: Testing and Respecifying Measurement Model}

At the first stage of the analysis process a measurement model was developed based on the conceptual model proposed by Wiedmann et al. (2007) which identifies the potential luxury value drivers. Measurement model included four value dimensions reflected by 12 value sub-dimension which were measured using a total of 46 items. Model was tested using confirmatory factor analysis (CFA) and maximum likelihood estimation technique. Fit statistics revealed that original model of Wiedmann et al. (2007) did not display an adequate fit to the observed data $(\chi 2(972)=2033.389, p<.01$ $\mathrm{CMIN} / \mathrm{DF}=2.028, \mathrm{GFI}=72, \mathrm{IFI}=.78, \mathrm{CFI}=.78$ and $\mathrm{RMSEA}=.067)$. Model was respecified by eliminating the problematic items and sub dimensions addressed by analysis results in a step by step procedure. Initially, two sub-dimension measured by a total of 6 items were dropped from the model. Namely, hedonic self directed plasure value was eliminated since the respective items were found to have insignificant factor loadings and uniquness value was elimated due to its low factor loading (estimate=.34). Additionally, a total of 13 items with low factor loadings or having high standardized residuals and modification indices were also deleted. The respesified model displayed in Figure 2 covered three second-order luxury value dimension reflected by 9 sub-dimensions that are measured by a total of 22 items and a first order value dimensions measured through 3 items.

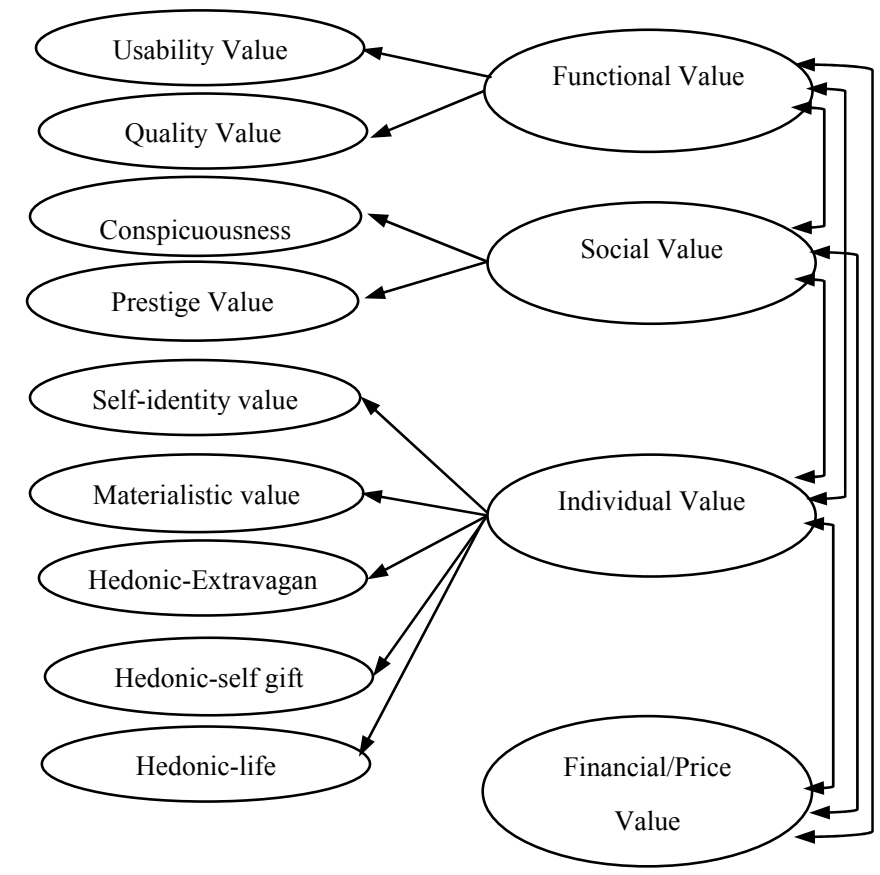

Figure 2. Respesified model

CFA was employed to test the respesified model and model was found to fit the data reasonably well: $\chi 2_{(260)}=395.937$, $\mathrm{CMIN} / \mathrm{DF}=1.523, \mathrm{GFI}=89, \mathrm{IFI}=.93, \mathrm{CFI}=.93$ and $\mathrm{RMSEA}=.047$. After overall evaluation, composite reliability and average variance exracted value were calculated and displayed in Table 2 to assess the validity and reliability of the 
scales. Accordingly, composite reliability (CR) scores range from 0.74 to 0.89 indicating that contructs are reliable (Fornell \& Larcker, 1981). As presented by Table 2 all factor loadings are large and significant $(\mathrm{p}<0.01)$ providing support for convergent validity. Also average variance extracted scores (AVE) which ranges from 0.56 to 0.69 provide additional evidence regarding convergent validity (Fornell \& Larcker, 1981). Discriminant validity was checked by comparing AVE of each construct with their squared inter-construct correlation coefficients presented in Table 3 . Table 4 shows the intercorrelations across the seven constructs in the study. The relatively higher AVE values provided evidence regarding the discriminant validity of the constructs (Fornell \& Larcker, 1981).

Table 2. Factor Loadings and Reliability Scores

\begin{tabular}{|c|c|c|c|c|c|c|c|c|c|c|c|c|}
\hline & \multicolumn{2}{|c|}{$\begin{array}{l}\text { first order } \\
\text { loadings }\end{array}$} & \multirow{2}{*}{$\begin{array}{l}\text { d. factor } \\
\text { Split } \\
\text { data2 } \\
\text { Combin } \\
\text { ed } \\
\text { measure } \\
\text { ment } \\
\text { model }\end{array}$} & \multirow{2}{*}{$\begin{array}{l}\text { second o } \\
\text { loadings } \\
\text { Split } \\
\text { data1 } \\
\text { Luxury } \\
\text { value } \\
\text { measurem } \\
\text { ent model }\end{array}$} & \multirow{2}{*}{$\begin{array}{l}\text { order std. } \\
\text { Split } \\
\text { data2 } \\
\text { Luxury } \\
\text { value } \\
\text { measure } \\
\text { ment } \\
\text { model }\end{array}$} & \multirow{2}{*}{\begin{tabular}{l}
\multicolumn{1}{c}{ factor } \\
Split \\
data2 \\
Combin \\
ed \\
measure \\
ment \\
model
\end{tabular}} & \multirow[b]{2}{*}{$\begin{array}{l}\text { CR } \\
\text { Split } \\
\text { data1 } \\
\text { Luxury } \\
\text { value } \\
\text { measure } \\
\text { ment } \\
\text { model }\end{array}$} & \multicolumn{5}{|c|}{ AVE } \\
\hline & $\begin{array}{l}\text { Split } \\
\text { data1 } \\
\text { Luxury } \\
\text { value } \\
\text { mm }\end{array}$ & $\begin{array}{l}\text { Split } \\
\text { data2 } \\
\text { Luxury } \\
\text { value } \\
\text { measure } \\
\text { ment } \\
\text { model }\end{array}$ & & & & & & $\begin{array}{l}\text { Split data2 } \\
\text { Luxury } \\
\text { value } \\
\text { measureme } \\
\text { nt model }\end{array}$ & $\begin{array}{l}\text { Split } \\
\text { data2 } \\
\text { Combine } \\
\text { d } \\
\text { e measure } \\
\text { ment } \\
\text { model }\end{array}$ & $\begin{array}{l}\text { Split } \\
\text { data1 } \\
\text { Luxury } \\
\text { value } \\
\text { measure } \\
\text { ment } \\
\text { model }\end{array}$ & $\begin{array}{l}\text { Split } \\
\text { data2 } \\
\text { Luxury } \\
\text { value } \\
\text { measure } \\
\text { ment } \\
\text { model }\end{array}$ & $\begin{array}{l}\text { Split } \\
\text { data2 } \\
\text { Combine } \\
\text { d } \\
\text { measure } \\
\text { ment } \\
\text { model }\end{array}$ \\
\hline FUNCTIONAL V & /ALUE & & & & & & .81 & .77 & .79 & .69 & .63 & .65 \\
\hline Usability value & & & & .906 & .827 & .792 & & & & & & \\
\hline $\mathrm{KD} 2$ & .621 & .654 & .653 & & & & & & & & & \\
\hline KD1 & .552 & .578 & .585 & & & & & & & & & \\
\hline KD3 & .603 & .624 & .618 & & & & & & & & & \\
\hline Quality value & & & & .746 & .791 & .825 & & & & & & \\
\hline KAL4 & .665 & .729 & .735 & & & & & & & & & \\
\hline KAL2 & .676 & .785 & .768 & & & & & & & & & \\
\hline KAL3 & .810 & .759 & .771 & & & & & & & & & \\
\hline SOCIAL VALUE & & & & & & & .74 & .67 & .67 & .60 & .52 & .52 \\
\hline Conspicuousness & value & & & .931 & .862 & .857 & & & & & & \\
\hline $\mathrm{CC} 3$ & .612 & .655 & .664 & & & & & & & & & \\
\hline $\mathrm{CC} 2$ & .774 & .716 & .707 & & & & & & & & & \\
\hline Prestige value & & & & .582 & .545 & .547 & & & & & & \\
\hline PV3 & .849 & .779 & .776 & & & & & & & & & \\
\hline PV2 & .784 & .852 & .854 & & & & & & & & & \\
\hline PV1 & .601 & .608 & .609 & & & & & & & & & \\
\hline INDIVIDUAL VA & ILUE & & & & & & .89 & .86 & 86 & .62 & .55 & .55 \\
\hline Self-identity value & & & & .657 & .658 & .656 & & & & & & \\
\hline $\sin 2$ & .760 & .779 & .781 & & & & & & & & & \\
\hline $\mathrm{SI} 3$ & .722 & .774 & .772 & & & & & & & & & \\
\hline Hedonic-Extrava & agance & & & .779 & .852 & .853 & & & & & & \\
\hline HE2 & .840 & .821 & .747 & & & & & & & & & \\
\hline HE3 & .817 & .752 & .834 & & & & & & & & & \\
\hline Hedonic-Life Enı & richment & & & .901 & .732 & .726 & & & & & & \\
\hline HLE1 & .759 & .745 & .687 & & & & & & & & & \\
\hline HLE2 & .704 & .836 & .770 & & & & & & & & & \\
\hline Hedonic-Self-Gif & ft Giving & & & .747 & .838 & .838 & & & & & & \\
\hline HS2 & .766 & .687 & .687 & & & & & & & & & \\
\hline HS3 & .733 & .769 & .769 & & & & & & & & & \\
\hline Materialistic valu & & & & .840 & .610 & .618 & & & & & & \\
\hline M3 & .486 & .394 & .391 & & & & & & & & & \\
\hline M5 & 609 & .610 & .607 & & & & & & & & & \\
\hline M6 & .642 & .667 & .672 & & & & & & & & & \\
\hline FINANCIAL/PRI & ICE VALI & UE & & & & & .79 & .82 & 82 & .56 & .61 & .61 \\
\hline P3 & .610 & .570 & .580 & & & & & & & & & \\
\hline $\mathrm{P} 2$ & .784 & .897 & .889 & & & & & & & & & \\
\hline $\mathrm{P} 1$ & .837 & .837 & .841 & & & & & & & & & \\
\hline BRAND TRUST & & & & & & & & & .77 & & & .53 \\
\hline BT3 & & & .766 & & & & & & & & & \\
\hline BT2 & & & .713 & & & & & & & & & \\
\hline BT1 & & & .712 & & & & & & & & & \\
\hline BRAND SATISFA & ACTION & & & & & & & & .76 & & & .51 \\
\hline S3 & & & .746 & & & & & & & & & \\
\hline $\mathrm{S} 4$ & & & .716 & & & & & & & & & \\
\hline REPURCHASE I & INTENTI & ION & & & & & & & .70 & & & .53 \\
\hline RI1 & & & .756 & & & & & & & & & \\
\hline $\mathrm{RI} 2$ & & & .734 & & & & & & & & & \\
\hline RI3 & & & .659 & & & & & & & & & \\
\hline
\end{tabular}


Table 3. Correlation estimates between luxury value dimensions ${ }^{1}$

\begin{tabular}{lllll}
\hline & PRICE & FUNCTIONAL & SOCIAL & INDIVIDUAL \\
& VALUE & VALUE & VALUE & VALUE \\
\hline PRICE VALUE & 1 & $.556^{\mathrm{a}}$ & $.260^{\mathrm{a}}$ & $.305^{\mathrm{a}}$ \\
FUNCTIONAL VALUE & $.597^{\mathrm{a}}$ & 1 & $.525^{\mathrm{a}}$ & $.526^{\mathrm{a}}$ \\
SOCIAL VALUE & .087 & $.569^{\mathrm{a}}$ & 1 & $.711^{\mathrm{a}}$ \\
INDIVIDUAL VALUE & .097 & $.406^{\mathrm{a}}$ & $.510^{\mathrm{a}}$ & 1 \\
\hline
\end{tabular}

${ }^{\mathrm{a}} \mathrm{p}<.01$

Table 4. Correlations estimates

\begin{tabular}{|c|c|c|c|c|c|c|c|}
\hline & $\begin{array}{l}\text { PRICE } \\
\text { VALUE }\end{array}$ & $\begin{array}{c}\text { FUNCTIONAL } \\
\text { VALUE }\end{array}$ & $\begin{array}{l}\text { SOCIAL } \\
\text { VALUE }\end{array}$ & $\begin{array}{l}\text { INDIVIDUAL } \\
\text { VALUE }\end{array}$ & $\begin{array}{c}\text { BRAND } \\
\text { SATISFACTION }\end{array}$ & $\begin{array}{l}\text { BRAND } \\
\text { TRUST }\end{array}$ & $\begin{array}{l}\text { REPURCHASE } \\
\text { INTENTION }\end{array}$ \\
\hline PRICE VALUE & 1 & & & & & & \\
\hline FUNCTIONAL VALUE & $.589^{\mathrm{a}}$ & 1 & & & & & \\
\hline SOCIAL VALUE & .088 & $.568^{\mathrm{a}}$ & 1 & & & & \\
\hline INDIVIDUAL VALUE & .099 & $.413^{\mathrm{a}}$ & $.513^{\mathrm{a}}$ & 1 & & & \\
\hline BRAND SATISFACTION & $.538^{\mathrm{a}}$ & $.673^{\mathrm{a}}$ & $.364^{\mathrm{a}}$ & $.287^{\mathrm{a}}$ & 1 & & \\
\hline BRAND TRUST & $.438^{\mathrm{a}}$ & $.569^{\mathrm{a}}$ & $.284^{\mathrm{a}}$ & $.473^{\mathrm{a}}$ & $.555^{\mathrm{a}}$ & 1 & \\
\hline REPURCHASE INTENTION & $.348^{\mathrm{a}}$ & $.506^{\mathrm{a}}$ & $.267^{\mathrm{a}}$ & $.283^{\mathrm{a}}$ & $.615^{\mathrm{a}}$ & $.597^{\mathrm{a}}$ & 1 \\
\hline
\end{tabular}

${ }^{\mathrm{a} p}<.01$

4.4.2 Second Stage: Testing Respecified Measurement Model

At the second stage the respecified model was tested using the second part of the data. Goodness of fit statistics provide evidence for acceptable model fit: $\chi 2(260)=375.476, \mathrm{p}<0.01 \mathrm{CMIN} / \mathrm{DF}=1,444$, GFI=.90, IFI $=.94, \mathrm{CFI}=.94$ and RMSEA $=.042$. According to CFA results convergent validity was achieved since all factor loadings are significant at .01 level and AVE scores were greater than .05. Discriminant validity was also evident since the variance explained by each construct is greater than the squared correlations between pairs of constructs (Fornell and Larcker, 1981). Composite reliability vaules ranging from .67 to .86 indicate the reliability of measures. Consequently, reliability and validity asssesment revealed that the scales for luxury value dimensions have satisfactory measurement qualities.

\subsubsection{Testing Overall Measeurement Model}

At the third stage an overall measurement model was developed by combining luxury value dimensions with the satisfaction, trust and repurchase intention. However, goodness-of-fit statisticss for this model were not satisfactory (e.g., $\mathrm{CFI}=0.84 ; \mathrm{GFI}=0.90$ ) since several items measuring the additional consructs (e.g. satisfaction) had low factor loadigs, high standardized resdiduals and modification indices. After the elimination of the five promlematic items CFA was reperformed. The model displayed an adequate fit to the observed data since all goodness-of-fit indices for this model were within the acceptable ranges $(\mathrm{CMIN} / \mathrm{DF}=1.456, \mathrm{GFI}=.87, \mathrm{IFI}=.93, \mathrm{CFI}=.93$ and $\mathrm{RMSEA}=.043)$ although resulting chisquare statistic was found to be significant $\left[\chi^{2}(465)=677.007, p<0.01\right]$. Additionaly, significant factor loadings $(\mathrm{p}<.01)$ and AVE scores ranging from .51 to .65 provided support for convergent validity. Discriminant validity were also evident since the AVE scores were all greater than the squared latent factor correlations between pairs of constructs (Fornell \& Larcker, 1981). Finally, CR scores ranged from .67 to .86 incicating accceptable level of contruct reliabilities. Overall, anaysis results provided satisfactory evindence regarding reliability and validity of the measures.

\subsection{Hypothesis Testing}

The hypothesized set of relationships shown in the Figure 1 was tested using maximum likelihood estimation technique. Although chi-square statistic was found to be significant $\left(\chi_{(469)}^{2}=677.653, p<0.0\right)$ probably due to the relatively large sample size, estimation resulted in an acceptable model fit $\left(\chi^{2} / \mathrm{df}=1.45\right.$; GFI=.87, IFI=.93, CFI=.93 and RMSEA=.042). As the squared multiple correlations revealed the model explains a substantial amount of the variance in satisfaction, trust and repurchase intention, respectively $49 \%, 47 \%$ and $47 \%$. Table 5 presents the parameter estimates for the hypothesized relationships. Accordingly six of eleven hypotheses were supported.

\footnotetext{
1 Upper part of the table represent the correlation coefficients among latent factors for sample 1 while the part below represent the correlation coefficients for sample 2
} 
Table 5. Structural parameter estimates

\begin{tabular}{|c|c|c|c|c|}
\hline & Estimate & Std Estimate & C.R. & $\mathrm{P}$ \\
\hline H1a- FUNCTIONAL VALUE $\rightarrow$ BRAND SATISFACTION & .719 & .505 & $2.41 * *$ & .008 \\
\hline H1b-SOCIAL VALUE $\rightarrow$ BRAND SATISFACTION & .044 & .044 & .274 & .392 \\
\hline H1c-INDIVIDUAL VALUE $\rightarrow$ BRAND SATISFACTION & .039 & .032 & .328 & .372 \\
\hline H1d-PRICE VALUE $\rightarrow$ BRAND SATISFACTION & .175 & .227 & $1.72 *$ & .043 \\
\hline H2a-FUNCTIONAL VALUE $\rightarrow$ BRAND TRUST & .386 & .262 & 1.28 & .101 \\
\hline H2b-SOCIAL VALUE $\rightarrow$ BRAND TRUST & -.162 & -.156 & -.99 & .160 \\
\hline H2c-INDIVIDUAL VALUE $\rightarrow$ BRAND TRUST & .447 & .355 & $3.47 * *$ & .001 \\
\hline H2d-PRICE VALUE $\rightarrow$ BRAND TRUST & .091 & .114 & .958 & .169 \\
\hline H3-BRAND SATISFACTION $\rightarrow$ BRAND TRUST & .283 & .274 & $2.15 *$ & .016 \\
\hline H4-BRAND SATISFACTION $\rightarrow$ REPURCHASE INTENTION & .456 & .410 & $3.97 * *$ & .001 \\
\hline H5-BRAND TRUST $\rightarrow$ REPURCHASE INTENTION & .395 & .367 & $3.75 * *$ & .001 \\
\hline
\end{tabular}

In support of $\mathrm{H} 1 \mathrm{a}$ and H1d the findings revealed that functional $(.505, \mathrm{p}<.01)$ and price value $(.227, \mathrm{p}<.05)$ have significant encouraging effects on brand satisfaction while impacts of individual value and social value were found to be insignificant which leads to rejection of $\mathrm{H} 1 \mathrm{~b}$ and $\mathrm{H} 1 \mathrm{c}$. Specifically functional value referring the perception of product usability and quality appeared as the most important factor in developing consumer satisfaction for a luxury brand. In turn brand satisfaction had significant positive effects on brand trust $(.274, \mathrm{p}<.05)$ and repurchase intention $(.410, \mathrm{p}<.01)$ as hypothesized by H1c and H4. Only one of the four hypotheses regarding the antecedents of brand trust was supported. Individual value was the sole factor having a significant promoting impact on developing trust meaning that mostly hedonic benefits provided by the brand is critical building trust in a luxury brand. Thus $\mathrm{H} 2 \mathrm{c}$ was supported. Finally, the enhancing effect of trust on repurchase was tested in H5. The hypotheses was supported since trust had a relatively weaker but still significant positive effect on repurchase intention $(.367, \mathrm{p}<.01)$.

\section{Discussion}

Knowledge of luxury value and its effects are crucial for understanding the process leading to the willingness of consumers stay in long term relationship with a luxury brand (Hennigs et al., 2012). To expand the traditional understanding in repurchase intention this study investigated luxury value in line with the holistic perspective. On the basis of the literature review, a four-level of luxury value was proposed including functional value with the dimensions of usability value and quality value; social value with the dimensions of conspicuousness value and prestige value; individual value with the dimensions of self identity value, hedonic extravagance value, hedonic life enrichment value, hedonic self gift giving value and materialistic value and financial value. Then, we proposed promoting effects of these luxury value drivers on brand satisfaction and brand trust which is interrelated and both increase repurchase intention joint.

The study contributes to this type of research in line with Wiedmann et al.'s (2007) indication that depending on the research focus by exploring the mechanisms through which consumer's luxury value perception regarding brands, as well as the specific constituents of each, jointly influence a critical attitudinal factor that has long been accepted as the three important indicators of long-term competitive and strategic success in luxury product sellers, these are, brand satisfaction, brand trust and repurchase intention.

In other words, brand satisfaction, brand trust and repurchase intention were investigated as cognitive and affective consequences of functional, social, individual and price value provided by a luxury brand. Results provided evidence that individual level of luxury value plays a vital role in consumers' evaluation of and emotion induced by the experiences with luxury brands and indirectly influence to repurchase tendency. In this way, it is more clear through which routes consumers' positive attitudes towards a luxury brand may be formed, maintained or improved for a long-term competitive and strategic success in the luxury market.

Results of the study revealed that luxury value explains nearly half of the variance in consumer's satisfaction with a luxury brand. If a luxury brand arouses functional value and financial value, the individual will be enjoyed with consuming that brand and he/she will be satisfied his/her shopping experience of that brand. When a consumer believes that luxury goods are useful, new-fashioned and has a superior quality; he/she feels that his/her choice turned out better than expectations. Furthermore worthwhile economic value is another consideration for satisfying luxury consumers' needs.

The proposed model also explains a significant portion of the variance in brand trust $(47 \%)$ which is one of the key components for a long term relationship with a brand. The results indicated that satisfaction and individual value provided by the luxury brand are the main drivers of brand trust. However the dominant impact of individual value was evident showing that when consumer feels the pleasure of using luxury brands they are more likely to believe that the brand is reliable. Accordingly, as consumers' use of luxury brand as a treating, gift giving, stress reducing tool increase, trust in the brand also increase. 
The empirical results provided may help marketers to understand how each dimension of luxury value (i.e. social, individual, financial and functional) can contribute to Turkish consumers' attitudes toward luxury brands. For instance, deep understanding regarding the influencers of luxury value can help practitioners to create and deliver value and appropriate communication messages.

Furthermore, note that the largely theoretical discussions in the previous paragraphs also involve several practical implications for marketers of retail services. On the basis of the results, this paper addresses an interesting issue that is important to managers who have luxury product offerings. We suggest that marketers should understand the full breadth and depth of the luxury value effects on consumers' outcomes. The overall empirical results help marketers to understand how each dimension of luxury value (i.e. social, individual, financial and functional) can contribute to consumer behavioral intentions. For instance, deep understanding regarding the influencers of luxury value can help practitioners to create and deliver value and appropriate offers that address to the market demands. Therefore, building a strong relationship through luxury value can be considered as the key success factor for luxury brands.

One of the most interesting insights for managers who have luxury product offerings for Turkish market is provided by the finding that social value of a luxury brand has no impact on consumers' cognitions and affects. The use of the traditional prestige and conspicuity offerings of luxury brands in marketing communication messages must be deliberated since the symbolic benefits for the self-image of these brands are likely to have no contribution for consumers' attitudes. However, signaling hedonic benefits through communication campaign focusing the self-pleasure of using a luxury may support the repetitive purchasing of luxury brand. Moreover, marketing managers must consider the dominant role of price- quality evaluations for their offerings as the functional value and price value were found to be key drivers for consumer satisfaction.

Finally, two main limitations of the research must be noted. First of all, this study takes into consideration of only one category of luxury products. Further studies may include different types of luxury products and service providers such as restaurants, hotels etc. as research object. One other limitation of this study is using convenience sampling technique and focus on graduate and undergraduate students. This limitation prevents to generalize the findings. Future studies with a more heterogenic sample covering different age and occupational groups are needed.

\section{References}

Aaker, D. A. (2009). Managing brand equity. Simon and Schuster.

Atwal, G., \& Williams, A. (2009). Luxury brand marketing-the experience is everything!. Journal of Brand Management, 16(5), 338-346. http://dx.doi.org/10.1057/bm.2008.48

Berthon, P., Pitt, L., Parent, M., \& Berthon, J. P. (2009). Aesthetics and Ephemerality. California Management Review, 52(1). http://dx.doi.org/10.1525/cmr.2009.52.1.45

Caro, L. M., \& Garcia, J. A. M. (2007). Measuring perceived service quality in urgent transport service. Journal of Retailing and Consumer Services, 14(1), 60-72. http://dx.doi.org/10.1016/j.jretconser.2006.04.001

Chandon, J. L., Laurent, G., \& Valette-Florence, P. (2016). Pursuing the concept of luxury: Introduction to the JBR Special Issue on "Luxury Marketing from Tradition to Innovation". Journal of Business Research, 69(1), 299-303. http://dx.doi.org/ 10.1016/j.jbusres.2015.08.001

Chattalas, M., \& Shukla, P. (2015). Impact of value perceptions on luxury purchase intentions: a developed market comparison. Luxury Research Journal, 1(1), 40-57. http://dx.doi.org/10.1504/LRJ.2015.069806

Chaudhuri, A., \& Holbrook, M. B. (2001). The chain of effects from brand trust and brand affect to brand performance: The role of brand loyalty. Journal of Marketing, 65, 81-93. http://dx.doi.org/10.1509/jmkg.65.2.81.18255

Cole, C. A., \& Balasubramanian, S. K. (1993), Age differences in consumers' search for information: Public policy implications, Journal of Consumer Research, 20(1), 157-169.

Cronin, J. J., Brady, M. K., \& Hult, G. T. M. (2000). Assessing the effects of quality, value, and customer satisfaction on customer behavioral intentions in service environments. Journal of Retailing, 76(2), 193-218. http://dx.doi.org/ 10.1016/S0022-4359(00)00028-2

Czepiel, J. A. (1990). Service encounters and service relationships: implications for research. Journal of Business Research, 20(1), 13-21. http://dx.doi.org/ 10.1016/0148-2963(90)90038-F

Davies, I. A., Lee, Z., \& Ahonkhai, I. (2012). Do customers care about ethical-luxury?. Journal of Business Ethics, 106(1), 37-51. http://dx.doi.org/ 10.1007/s10551-011-1071-y

Delgado-Ballester, E., \& Luis Munuera-Alemán, J. (2001). Brand trust in the context of customer loyalty. European Journal of Marketing, 35(11/12), 1238-1258. http://dx.doi.org/ 10.1108/EUM0000000006475 
Delgado-Ballester, E., \& Luis Munuera-Alemán, J. (2005). Does brand trust matter to brand equity?. Journal of product \& brand management, 14(3), 187-196. http://dx.doi.org/10.1108/10610420510601058

Delgado-Ballester, E., Munuera-Aleman, J. L., \& Yague-Guillen, M. J. (2003). Development and validation of a brand trust scale. International Journal of Market Research, 45(1), 35-54.

Dion, D., \& Arnould, E. (2011). Retail luxury strategy: assembling charisma through art and magic. Journal of Retailing, 87(4), 502-520. http://dx.doi.org/ 10.1016/j.jretai.2011.09.001

Dubois, B., \& Duquesne, P. (1993). The market for luxury goods: income versus culture. European Journal of Marketing, 27(1), 35-44. http://dx.doi.org/10.1108/03090569310024530

Eastman, J. K., Goldsmith, R. E., \& Flynn, L. R. (1999). Status consumption in consumer behavior: Scale development and validation. Journal of Marketing Theory and Practice, 41-52. http://dx.doi.org/10.1080/10696679.1999.11501839

Esch, F.-R., Langner, T., Schmitt, B. H., \& Geus, P. (2006). Are brands forever? How brand knowledge and relationships affect current and future purchases. Journal of Product \& Brand Management, 15(2), 98-105. http://dx.doi.org/10.1108/10610420610658938

Fitzsimons, G. J., Greenleaf, E. A., \& Lehmann, D. R. (1997), Decision and consumption satisfaction: Implications for channel relations, Working paper, Columbia Business School, Columbia University.

Fornell, C., \& Larcker, D. F. (1981), Evaluating structural equation models with unobservable variables and measurement error, Journal of Marketing Research, 18(01), 39-50.

Garbarino, E., \& Johnson, M. S. (1999). The different roles of satisfaction, trust, and commitment in customer relationships. the Journal of Marketing, 70-87. http://dx.doi.org/ 10.2307/1251946

Gibson, H. (2005). Towards an understanding of 'why sport tourists do what they do'. Sport in Society, 8(2), 198-217. http://dx.doi.org/ 10.1080/17430430500087369

Grossman, G. M., \& Shapiro, C. (1986). Foreign counterfeiting of status goods (No. w1915). National Bureau of Economic Research. http://dx.doi.org/ 10.3386/w1915

Ha, H. Y., \& Perks, H. (2005). Effects of customer perceptions of brand experience on the web: Brand familiarity, satisfaction and brand trust. Journal of Customer Behaviour, 4(6), 438-452. http://dx.doi.org/ 10.1002/cb.29

Han, Y. J., Nunes, J. C., \& Drèze, X. (2013). Signaling status with luxury goods: The role of brand prominence. International Retail and Marketing Review, $9(1), 1-22$. http://dx.doi.org/10.1509/jmkg.74.4.15

Hansen, J., \& Wänke, M. (2011). The abstractness of luxury. Journal of Economic Psychology, 32(5), 789-796. http://dx.doi.org/ 10.1016/j.joep.2011.05.005

Hasan, H. F. A., Ilias, A., Rahman, R. A., \& Razak, M. Z. A. (2009). Service quality and student satisfaction: A case study at private higher education institutions. International Business Research, 1(3),163. http://dx.doi.org/10.5539/ibr.v1n3p163

Heine, K., \& Phan, M. (2011). Trading-up mass-market goods to luxury products. Australasian Marketing Journal (AMJ), 19(2), 108-114. http://dx.doi.org/ 10.1016/j.ausmj.2011.03.001

Hennigs, N., Wiedmann, K. P., Klarmann, C., Strehlau, S., Godey, B., Pederzoli, D., \& Oh, H. (2012). What is the Value of Luxury? A Cross - Cultural Customer Perspective. Psychology \& Marketing, 29(12), 1018-1034. http://dx.doi.org/ 10.1002/mar.20583

Huber, F., Herrmann, A., \& Wricke, M. (2001). Customer satisfaction as an antecedent of price acceptance: results of an empirical study. Journal of Product \& Brand Management, 10(3), 160-169.

Hung, K. P., Huiling Chen, A., Peng, N., Hackley, C., Amy Tiwsakul, R., \& Chou, C. L. (2011). Antecedents of luxury brand purchase intention. Journal of Product \& Brand Management, 20(6), 457-467. http://dx.doi.org/10.1108/10610421111166603

Jakutis, A., \& Bakanauskas, A. (2010). Customer value: determination in undefined environment. Organizaciju Vadyba: Sisteminiai Tyrimai, (53), 7-18.

Jung Choo, H., Moon, H., Kim, H., \& Yoon, N. (2012). Luxury customer value. Journal of Fashion Marketing and Management: An International Journal, 16(1), 81-101. http://dx.doi.org/10.1108/13612021211203041

Kabadayi, E. T., \& Alan, A. K. (2012). Brand trust and Brand effect: Their strategic importance on brand loyalty. Journal of Global Strategic Management, June, 11, 81-88. 
Kapferer, J. N., \& Bastien, V. (2009). The specificity of luxury management: Turning marketing upside down. Journal of Brand Management, 16(5), 311-322. http://dx.doi.org/10.1057/bm.2008.51

Kastanakis, M. N., \& Balabanis, G. (2014). Explaining variation in conspicuous luxury consumption: An individual differences' perspective. Journal of Business Research, 67(10), 2147-2154.

Keng, C. J., Huang, T. L., Zheng, L. J., \& Hsu, M. K. (2007). Modeling service encounters and customer experiential value in retailing: An empirical investigation of shopping mall customers in Taiwan. International Journal of Service Industry Management, 18(4), 349-367.

Kim, W. G., Lee, Y. K., \& Yoo, Y. J. (2006). Predictors of relationship quality and relationship outcomes in luxury restaurants. Journal of Hospitality \& Tourism Research, 30(2), 143-169.

Lau, G. T. \& Lee, S. H. (1999). Consumers' trust in a brand and the link to brand loyalty, Journal of Market - Focused Management, 4 (4), 341-370.

Lee, J. H., \& Hwang, J. (2011). Luxury marketing: The influences of psychological and demographic characteristics on attitudes toward luxury restaurants. International Journal of Hospitality Management, 30(3), 658-669.

Li, G., Li, G., \& Kambele, Z. (2012). Luxury fashion brand customers in China: Perceived value, fashion lifestyle, and willingness to pay. Journal of Business Research, 65(10), 1516-1522.

Ling, K. C., Chai, L. T., \& Piew, T. H. (2010). The effects of shopping orientations, online trust and prior online purchase experience toward customers' online purchase intention. International Business Research, 3(3), 63.

Mathwick C., Malhotra N., \& Rigdon E. (2000), Experiential value: Conceptualization, measurement and application in the catalog and internet shopping environment, Journal of Retailing, 77, 40-44.

Mattila, A. (1999). Consumers value judgments: How business travelers evaluate luxury-hotel services. The Cornell Hotel and Restaurant Administration Quarterly, 40(1), 40-46.

Moliner, M. A., Sánchez, J., Rodríguez, R. M., \& Callarisa, L. (2007). Relationship quality with a travel agency: The influence of the postpurchase perceived value of a tourism package. Tourism and Hospitality Research, 7(3-4), 194-211.

Moorman, C., Deshpande, R., \& Zaltman, G. (1993). Factors affecting trust in market research relationships. the Journal of Marketing, 81-101.

Morgan, R. M., \& Hunt, S. D. (1994). The commitment-trust theory of relationship marketing. The Journal of Marketing, 20-38.

O'cass, A., \& McEwen, H. (2004). Exploring consumer status and conspicuous consumption. Journal of Consumer Behaviour, 4(1), 25-39.

Okonkwo, U. (2009). Sustaining the luxury brand on the Internet. Journal of Brand Management, 16(5), 302-310.

Oliver, R. L. (1980). A cognitive model of the antecedents and consequences of satisfaction decisions. Journal of Marketing Research, 460-469.

Punniyamoorthy, M., \& Raj, M. P. M. (2007). An empirical model for brand loyalty measurement. Journal of Targeting, Measurement and Analysis for Marketing, 15(4), 222-233.

Ranaweera, C., \& Prabhu, J. (2003). The influence of satisfaction, trust and switching barriers on customer retention in a continuous purchasing setting. International Journal of Service Industry Management, 14(4), 374-395.

Sharma, P. (2009). Country of origin effects in developed and emerging markets: Exploring the contrasting roles of materialism and value consciousness, Journal of International Business Studies, 42(2), 285-306.

Sheth, J. N., Newman, B. I., \& Gross, B. L. (1991). Why we buy what we buy: a theory of consumption values. Journal of Business Research, 22(2), 159-170.

Shukla, P., \& Purani, K. (2012). Comparing the importance of luxury value perceptions in cross-national contexts. Journal of Business Research, 65(10), 1417-1424.

Shukla, P., Shukla, E., \& Sharma, S. (2009). Conspicuous consumption in cross-national context: psychological and brand antecedents. Asia-Pacific Advances in Consumer Research (8, pp. 16-19). Duluth, MN: Association for Consumer Research.

Sirdeshmukh, D., Singh, J., \& Sabol, B. (2002). Consumer trust, value, and loyalty in relational exchanges. Journal of Marketing, 66(1), 15-37.

Smith, J. B., \& Colgate, M. (2007). Customer value creation: a practical framework. Journal of Marketing Theory and 
Practice, 15(1), 7-23.

Song, Y., Hur, W. M., \& Kim, M. (2012). Brand trust and affect in the luxury brand-customer relationship. Social Behavior and Personality: an international journal, 40(2), 331-338.

Srinivasan, R., Srivastava, R. K., \& Bhanot, S. (2014). A Study of the antecedents of purchase decision of luxury brands. Journal of Business and Management, (16/5), May, 99-101.

Stokburger-Sauer, N. E., \& Teichmann, K. (2013). Is luxury just a female thing? The role of gender in luxury brand consumption. Journal of Business Research, 66(7), 889-896.

Strizhakova, Y., Coulter, R. A., \& Price, L. L. (2008). Branded products as a passport to global citizenship: Perspectives from developed and developing countries. Journal of International Marketing, 16(4), 57-85.

Suto, M. (1979). Some Neglected Aspects of Veblen's Social Thought. Social Science Quarterly, 439-453.

Teimourpour, B., \& Hanzaee, K. H. (2011). The impact of culture on luxury consumption behavior among Iranian consumers. Journal of Islamic Marketing, 2(3), 309-328.

Truong, Y., \& McColl, R. (2011). Intrinsic motivations, self-esteem, and luxury goods consumption. Journal of Retailing and Consumer Services, 18(6), 555-561.

TUIK, Turkish Statistical Institute, http://www.tuik.gov.tr/PreHaberBultenleri.do?id=18616, 02.02.2016

Tynan, C., McKechnie, S., \& Chhuon, C. (2010). Co-creating value for luxury brands. Journal of Business Research, 63(11), 1156-1163.

Veblen, T. (1965). The Theory of the Leisure Class. 1899. AM Kelley, bookseller.

Vigneron, F., \& Johnson, L. W. (1999). A review and a conceptual framework of prestige-seeking customer behavior. Academy of Marketing Science Review, 1(1), 1-15.

Vigneron, F., \& Johnson, L. W. (2004). Measuring perceptions of brand luxury. The Journal of Brand Management, 11(6), 484-506.

Walsh, G., Shiu, E., Hassan, L. M., Michaelidou, N., \& Beatty, S. E. (2011). Emotions, store-environmental cues, store-choice criteria, and marketing outcomes. Journal of Business Research, 64(7), 737-744.

Wang, P. Z., \& Waller, D. S. (2006). Measuring customer vanity: A cross-cultural validation. Psychology and Marketing, 23(8), 665.

Westbrook, R. A. \& Oliver, R. L. (1981). Developing better measures of consumer satisfaction: Some preliminary results, in NA - Advances in Consumer Research Volume 08, eds. Kent B. Monroe, Ann Abor, MI : Association for Consumer Research, 94-99.

Wiedmann, K. P., Hennigs, N., \& Siebels, A. (2007). Measuring customers' luxury value perception: A cross-cultural framework. Academy of Marketing Science Review, 7(7), 333-361.

Wiedmann, K. P., Hennigs, N., \& Siebels, A. (2009).Value - based segmentation of luxury consumption behavior. Psychology \& Marketing, 26(7), 625-651.

Wirtz, J., \& Bateson, J. E. (1999). Customer satisfaction with services: integrating the environment perspective in services marketing into the traditional disconfirmation paradigm. Journal of Business Research, 44(1), 55-66.

Wu, C. H. J., \& Liang, R. D. (2009). Effect of experiential value on customer satisfaction with service encounters in luxury-hotel restaurants. International Journal of Hospitality Management, 28(4), 586-593.

Xingyuan, W., Li, F., \& Wei, Y. (2010). How do they really help? An empirical study of the role of different information sources in building brand trust. Journal of Global Marketing, 23(3), 243-252.

Zboja, J. J., \& Voorhees, C. M. (2006). The impact of brand trust and satisfaction on retailer repurchase intentions. Journal of Services Marketing, 20(6), 381-390.

Zeithaml, V. A. (1988). Consumer perceptions of price, quality, and value: a means-end model and synthesis of evidence. The Journal of marketing, 2-22.

\section{Copyrights}

Copyright for this article is retained by the author(s), with first publication rights granted to the journal.

This is an open-access article distributed under the terms and conditions of the Creative Commons Attribution license (http://creativecommons.org/licenses/by/3.0/). 